\title{
Characteristics of atypical Huperzia selago subsp. arctica habitats to the south of distribution area
}

\author{
Ilona Jukoniené ${ }^{*}$, Rasa Dobravolskaitė, Jūratė Sendžikaitè \\ Nature Research Centre, Institute of Botany, Žaliujuy Ežeru 49, 08406 Vilnius, Lithuania
}

\section{Abstract}

Two localities for Huperzia selago subsp. arctica are recorded from Lithuania, to the south of its known distribution area. The habitats of this subspecies are cutover peatlands whose natural vegetation was disturbed 6-8 years ago during peat exploitation. One of the dominant species of latest vegetation cover is the invasive bryophyte Campylopus introflexus. Characteristics of the habitats of $H$. selago subsp. arctica and the frequency of this taxon in populations were analysed.

Keywords: Campylopus introflexus, cutover peatlands, distribution area, Huperzia selago subsp. arctica, Lithuania, population

\section{Introduction}

The species Huperzia selago Bernh. s.l. comprises an assemblage of morphologically diverse plants [1]. Those from high- and mid-alpine habitats are low-growing and compact, yellow-green and have appressed leaves. Moreover, they produce abundant bulbils. Southern lowland plants are larger, very dark green, have more or less patent leaves, and bulbils are sparse or absent [2]. Such variation is treated differently by European botanists. According to Elven [3], this variation may be due to three possibilities: $(\boldsymbol{i}) H$. selago represents a single undifferentiated species, $(\boldsymbol{i} i)$ it consists of a number of races or subspecies, or (iii) it consists of several species. Russian authors, however, have applied for some taxa to be elevated to the rank of species, e.g. H. selago, $H$. petrovii and $H$. arctica [4] or $H$. selago, $H$. appressa, and $H$. arctica $[5,6]$. The most recent western European treatments, based on a hypothesis of gradual divergence of races or species, recognize only one species, $H$. selago, consisting of two or three subspecies, namely, the temperate to boreal subsp. selago, a northern alpine-boreal to southern arctic subsp. appressa (not accepted by all authorities), and a northern arctic subsp. arctica [3]. Most northwestern European authors [2,7-9] recognise just two subspecies (H. selago subsp. selago and H. selago subsp. arctica) and tend to regard $H$. selago subsp. appress $a$ as intermediate between selago and arctica. It is thus not accepted as a taxon and plants conforming to subsp. apressa are assigned to subsp. arctica. Such distinction is recognized in literature such as Flora Europaea [10],

*Corresponding author. Email: ilona.jukoniene@botanika.lt

This is an Open Access digital version of the article distributed under the terms of the Creative Commons Attribution 3.0 License

(creativecommons.org/licenses/by/3.0/), which permits redistribution, commercial and non-commercial, provided that the article is properly cited.
Flora Nordica [2] and the New Flora of the British Isles [11]. This last classification, namely, that $H$. selago consists of two subspecies, is the one adopted in the present paper.

The subspecies arctica has a circumpolar distribution with a distribution range that includes both arctic and boreal zones. This subspecies has been recorded from Finland, Iceland, Norway, Sweden and the northern part of Russia. Solitary records are also known from Scotland [12]. Although $H$. selago is distributed throughout the Baltic countries, no data on subspecies arctica are known from Lithuania, Latvia and Estonia [13-15]. Furthermore, this subspecies is not recorded in the floras or plant lists of the neighbouring countries, Belarus [16] and Poland [17]. As a result, the southernmost localities known for this subspecies occur in the southern parts of Finland and Sweden. Its abundant production of bulbils is one of the characters used to distinguish $H$. selago subsp. arctica from $H$. selago subsp. selago. According to Naujalis [18] propagation of $H$. selago in Lithuanian populations is mainly by means of spores, not bulbils. However, mountain populations of this species in Poland are characterized by the presence of numerous vegetative propagules [19].

This paper characterizes the habitats of Lithuanian H. selago subsp. arctica (i.e. populations found outside and to the south of its typical distribution area). The main aim was to compare the habitats occupied by this subspecies with those in the northern part of its distribution range and to assess the possibility that $H$. selago subsp. arctica might also occur in other localities throughout Lithuania and its neighbouring territories. The influence of the distribution of the invasive moss Campylopus introflexus upon the frequency of $H$. selago subsp. arctica was also studied.

\section{Material and methods}

\section{Study sites}

Huperzia selago subsp. arctica (Fig. 1) was recorded from two peatlands in Lithuania - Sulinkiai (Radviliškis distr., 
N 55 $06^{\prime} 31^{\prime \prime}$; E $24^{\circ} 56^{\prime} 58^{\prime \prime}$ ) and Paraisčiai (Anykščiai distr., N 55 $32^{\prime} 39^{\prime \prime}$; E 2325'10"; Fig. 2).

The first locality is situated in the eastern part of Samogitian Highland, the second, in the northern part of the Central Lithuanian Plain. Both localities occur in the northern part of Lithuania and, according to thermal indicators, belong to the same agroclimatic subregion. A feature of this subregion is that the sum of active temperatures $\left(\Sigma \mathrm{T}>10^{\circ} \mathrm{C}\right)$ is 2100 $2200^{\circ} \mathrm{C}$, the mean absolute minimum temperatures are -24 to $-26^{\circ} \mathrm{C}$, it has an annual precipitation of 500-600 $\mathrm{mm}$ and displays a Selyaninov's hydrothermal coefficient (HTC) of 1.3-1.9 [20,21].

Peat is still intensely extracted in many parts of the peatlands, and the latter are drained by numerous, regularly spaced ditches (every $20 \mathrm{~m}$ ), as well as other surrounding ditches. Different degrees of exploitation, or simply because the working of some parts of the peatlands has been abandoned, has resulted in the generation of new habitats that display the full range of wetland complex formation, from bare areas devoid of vegetation to stands of reeds, rushes and shrub thickets, as well as open areas occupied by shallow ponds [22].

Huperzia selago subsp. arctica was recorded from both peatlands (middle of the Sulinkiai peatland and in the western part of Paraisčiai peatland) in a single segment (20 m wide) of the former peat-cutting fields, where peat exploitation was suspended 6-8 years ago.

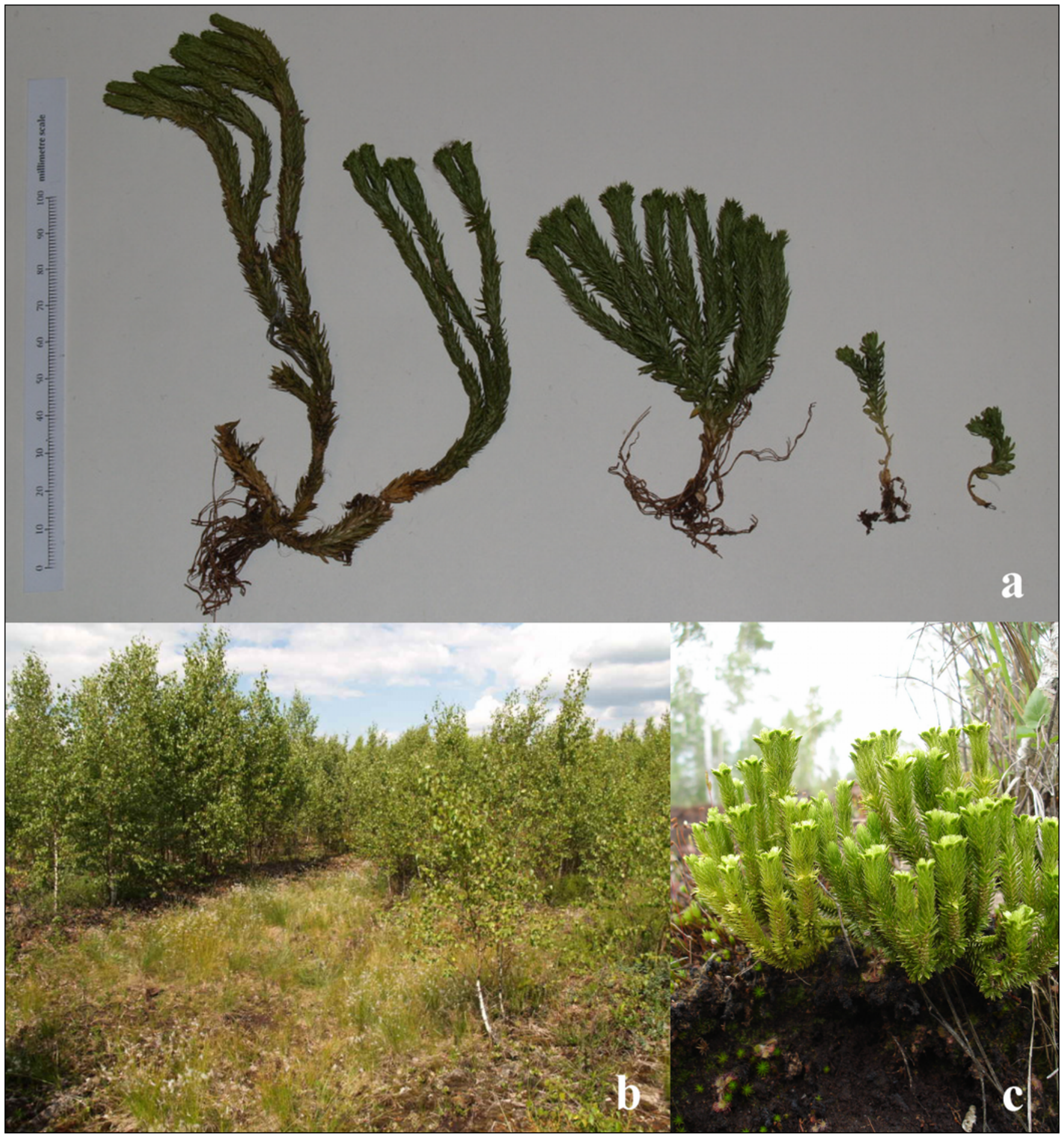

Fig. 1 Huperzia selago subsp. arctica. a Individuals of various size and age from Sulinkiai peatland. b The Sulinkiai peatland habitat. c General view. 


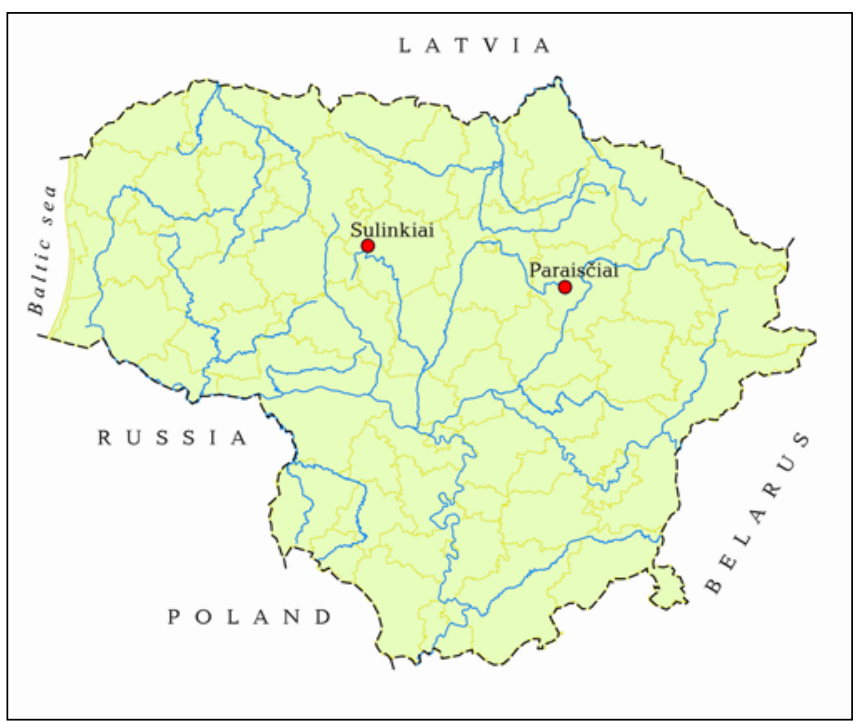

Fig. 2 Map of Lithuania showing localities where Huperzia selago subsp. arctica was found.

\section{Data collection and analysis}

In this paper, we followed Kukkonen's [2] treatment of Huperzia selago subsp. arctica: Huperzia selago subsp. arctica (Grossh. ex Tolm.) Á. Löve \& D. Löve, Bot. Not. 114: 35 (1961) - Huperzia arctica Sipliv., Novosti Sist. Vyssh. Rast. 10: 347 (1973) - Lycopodium selago subsp. arcticum Grossh. ex Tolm., Bot. Mater. Gerb. Bot. Inst. Komarova Akad. Nauk SSSR 20: 39 (1960).

Huperzia appalachiana Beitel \& Mickel (1992).

Lycopodium selago var. appressum Bach Pyl ex Desv. (1827) - Huperzia appressa (Bach Pyl ex Desv.) Á. Löve \& D. Löve (1961) - H. selago subsp. appressa (Bach Pyl ex Desv.) D. Löve in Á. Löve \& D. Löve (1961) - H. selago subsp. appressa (Desv.) Kukkonen (1984).

Voucher specimens of $H$. selago subsp. arctica were deposited in the Herbarium of the Institute of Botany at the Nature Research Center, Vilnius (BILAS; No. 76443 and 76444) and in the Herbarium of the Finnish Museum of Natural History, Helsinki (H; No. 1755878).

The specimens were indentified on the basis of morphological features (color, length and width of shoots, position and length of leaves, presence of bulbils, degree of serration of leaf apex) $[2,10,11]$.

Huperzia selago subsp. arctica was recorded in 2010 and 2011 during investigations into the distribution of the invasive moss Campylopus introflexus in cutover peatlands throughout Lithuania (in total, 32 peatlands were investigated). In order to characterize these habitats, peat analysis was performed. Peat samples were taken from the surface layer of each habitat (up to $5 \mathrm{~cm}$ depth) at ten randomly selected points and a pooled sample (approx $500 \mathrm{~g}$ of peat) prepared. The analyses of peat parameters were carried out at the Labtarna chemical laboratory, Vilnius. Peat $\mathrm{pH}$ was determined using glass electrode in a 1:5 (volume fraction) suspension of soil in potassium chloride solution (LST ISO 10390:2005). Total nitrogen was determined by the modified Kjeldahl method (LST EN 13654-1:2002), total phosphorus - by spectrophotometric method after mineralisation (standard operating procedure No. 5.4-145), potassium content was determined by atomic absorbtion spectrometry method after dissolution (ISO 14869-2:2002) and organic matter content (OMC) - by a high temperature combustion gravimetric method (LST EN 13039:2003).
The percentage cover of Huperzia selago subsp. arctica in the Sulinkiai peatland was estimated for $40(0.5 \times 0.5 \mathrm{~m})$ neighbouring sections of a linear transect (20 m length). The linear transect crossed the main distribution area of the investigated subspecies and it ran $4 \mathrm{~m}$ from, and parallel to a drainage ditch. Furthermore, for ten study plots, each measuring $1 \mathrm{~m}^{2}$ and distributed every other meter along the transect, every vascular plant and bryophyte species, as well as the common ground cover of herbs and bryophytes were recorded, and the number of individuals plants of $H$. selago subsp. arctica counted. For accurate determination of cover and number of individual plants, a quadrat of $0.5 \times 0.5 \mathrm{~m}$ was used, where the total cover or number of species is the sum of the records from these squares. The Spearman's correlation coefficient (SPSS version 16) was used to test for any correlation between the frequency of $H$. selago subsp. arctica (percentage cover and number of individuals) and the cover of bryophyte and herb layers in the study plots.

In the Paraisčiai peatland, where surrounding secondary vegetation was removed as part of the management of the peat cutting field, and where only solitary individuals of $H$. selago subsp. arctica were found, no detailed studies were carried out.

Botanical nomenclature follows Gudžinskas [23] for vascular plants and Hill et al. [24] for mosses.

Eight indicator values for vascular plant species, and five indicator values for bryophytes along a hemerophilous-hemerophobous gradient were recognized following FloraWeb [25] and Dierßen [26], respectively.

\section{Results}

\section{Characteristics of habitats}

Habitats in both localities were characterized by their similar peat acidity and low quantities of total phosphorus. However, they differed in the amounts of total nitrogen and total potassium present. The amounts of organic matter showed that the Paraisčiai peatland habitat was more advanced in terms of peat degradation (Tab. 1).

Tab. 1 Peat parameters for habitats of Huperzia selago subsp. arctica.

\begin{tabular}{lcc} 
& \multicolumn{2}{c}{ Peatlands } \\
\cline { 2 - 3 } Peat parameters & Paraisčiai & Sulinkiai \\
\hline $\mathrm{N}(\mathrm{mg} / \mathrm{kg})$ & 12535.00 & 20899.00 \\
$\mathrm{P}(\mathrm{mg} / \mathrm{kg})$ & 200.00 & 218.44 \\
$\mathrm{~K}(\mathrm{mg} / \mathrm{kg})$ & 521.00 & 163.00 \\
Organic matter $\%$ & 80.39 & 93.56 \\
$\mathrm{pH}$ & 4.10 & 4.00
\end{tabular}

In Paraisčiai, the peatland vegetation had been disturbed. Solitary individuals of $H$. selago subsp. arctica were occasionally surrounded by mats of Polytrichum strictum and Campylopus introflexus.

Twenty-eight vascular plant species were recorded from the Sulinkiai habitat (five of these were from outside the study plots). The tree layer had not yet developed. Young trees of Betula pendula were recorded from $40 \%$ of the study plots 
and measured up to $2 \mathrm{~m}$ in height. Herb layer cover in the study plots ranged from $10 \%$ to $80 \%$ (mean $30.5 \%$ ). The most frequent species present were Trichophorum alpinum (90\%), Pilosella cymosa aggr. (90\%), Eriophorum angustifolium (70\%) and Pyrola rotundifolia (70\%). Moss cover ranged from 30\% to $90 \%$ (mean $67.5 \%$ ), and was formed mainly of two species, the invasive moss Campylopus introflexus and the native moss Polytrichum strictum (Tab. 2).

\section{Abundance of Huperzia selago subsp. arctica in the Sulinkiai peatland}

Individuals of Huperzia selago subsp. arctica were recorded from $82 \%$ of linear transect sections (Fig. 3), and from all study plots (Tab. 2). Percentage cover was similar in both (max. 1520\%; Fig. 3, Tab. 2).

The mean number of individuals in ten study plots was 29 (range 2-96) and the population was composed of individuals of various size and age (Fig. 1a).

Tab. 2 Characteristics of species recorded from the habitat of Huperzia selago subsp. arctica.

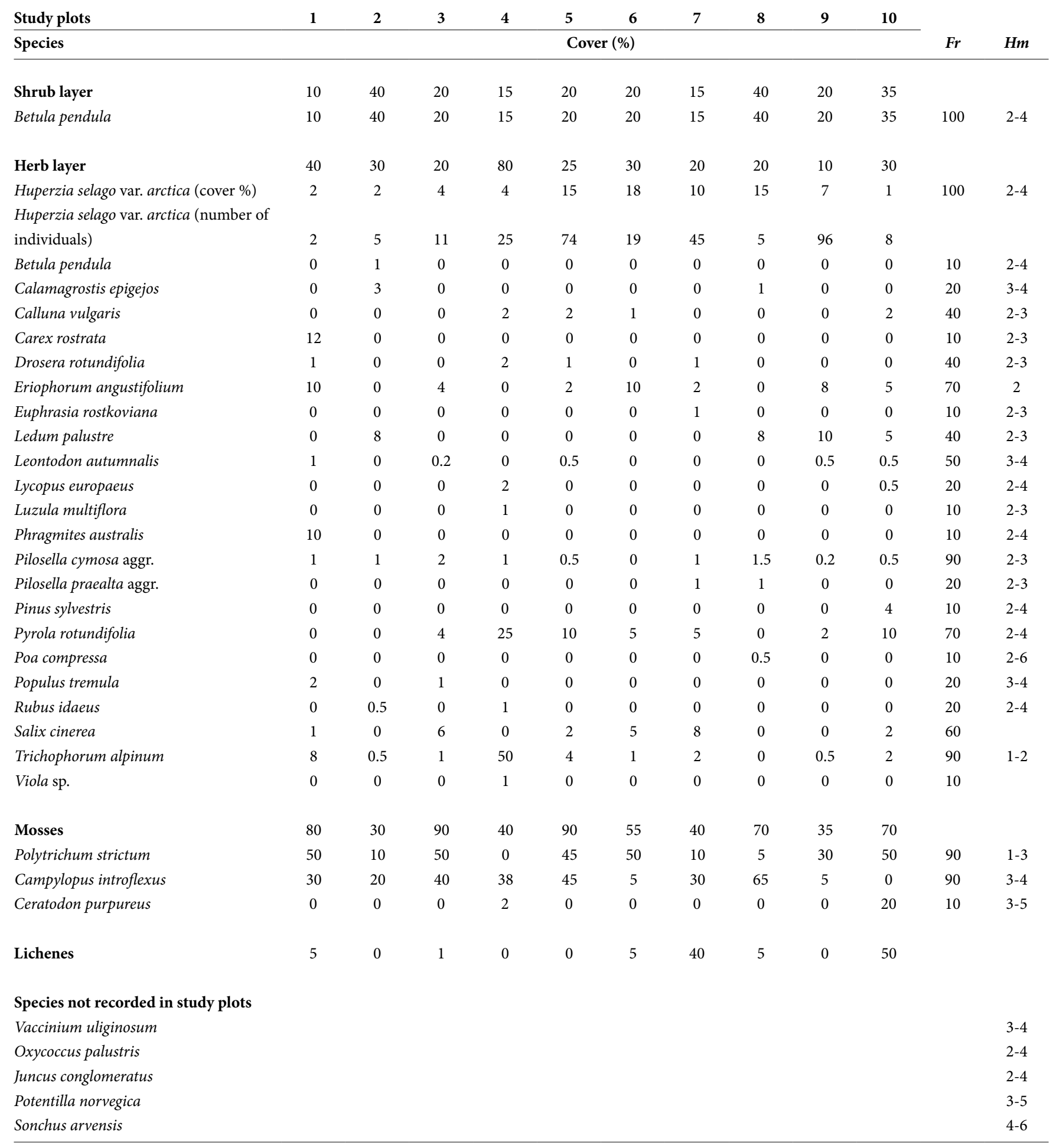

$\mathrm{Fr}$ - frequency of species (\%) in 10 study plots; $\mathrm{Hm}$ - index of hemeroby based on FloraWeb [25] and Dier $\beta$ en [26]. 
No correlation was observed between the mean number of individuals and the percentage cover of $H$. selago subsp. arctica (Spearman rank correlation, $p>0.05$ ). Both $H$. selago subsp. arctica cover and the number of its individuals tended to decrease as the herb layer cover increased, but no significant correlation was seen (Spearman rank correlation, in all cases $p>0.05)$. Furthermore, no correlation was found between the frequency of individuals of $H$. selago subsp. arctica and the percentage cover of mosses (total cover or cover by the separate species, Campylopus introflexus and Polytrichum strictum). The frequency of individuals of $H$. selago subsp. arctica was similar for both plots, regardless of whether they consisted of bare peat or had almost full moss cover (Tab. 2).

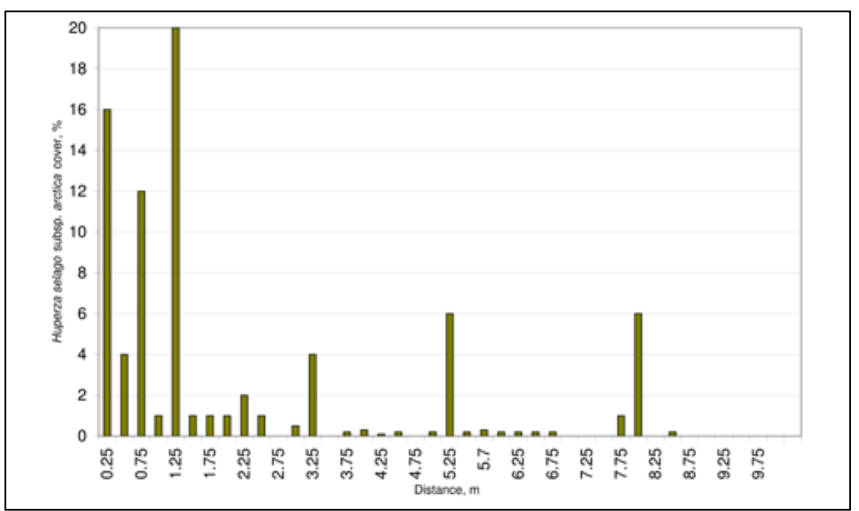

Fig. 3 Frequency (percentage cover) of Huperzia selago subsp. arctica in 40 plots $\left(0.25 \mathrm{~m}^{2}\right)$ along a linear transect $(20 \mathrm{~m}$ long) in Sulinkiai peatland.

\section{Discussion}

Lithuania occurs in the hemiboreal region of the temperate biogeographical zone [27]. Therefore, the localities presented here, and for which this subspecies has been recorded, lie to the south of its main distribution area, which covers both arctic and boreal zones. These localities are also subject to climatic conditions different from those of the main distribution area, since Lithuania extends into the temperate zone and is thus subject to a climate intermediate between West European maritime and East European continental types [28].

The subspecies, based on its ecology in northern territories, is a calcifuge, preferring rather dry sites with bare peat [2]. Consequently, the peat parameters of Lithuanian habitats closely match its requirements.

The composition of plant species cover in the Sulinkiai habitat reflects both the primary nature of the habitat and the effect of human impact upon it. The most recent herb cover was formed by secondary succession, as bog species, tree seedlings and various other species regenerated to occupy open sites (Tab. 2). Despite anthropogenic influences on the habitat, most species in the herb layer were those that were able to tolerate low or moderate levels of human impact $(39 \%$ and $35 \%$, respectively). Several species (Sonchus arvensis, Poa compressa and Potentilla norvegica), however, were characteristic of habitats strongly influenced by man [25], but in the studied habitat, they grew only sporadically. Conversely, Trichophorum alpinum, the only vascular plant species that preferred habitats subject to moderate human impact [25], was the most frequent in the herb layer. It is likely that this species spread from the less disturbed edges of the ditch that separates peat cutting plots. Another characteristic species of mires, Eriophorum angustifolium is known to be a primary colonizer of bare peat [29], whereas other common herbaceous species (Pyrola rotundifolia and Pilosella cymosa aggr.) are characteristic of various types of disturbed habitats [30,31]. Owing to the distribution of species of various ecological groups, the herb layer was relatively rich, in contrast to the moss cover, which was species poor. The abundance of the invasive moss Campylopus introflexus reflected anthropogenic influence on the habitat.

Low vegetation is characteristic of those habitats in the northern parts of the subspecies' distribution area [8]. Consequently, apart from anthropogenic factors, the habitats of Huperzia selago subsp. arctica in Lithuania are similar to its northern habitats. Clearly, owing to high representation of tree species in the shrub layer, and shrub species (Salix cinerea) in the herb layer, the habitat structure will change over time. In contrast to those habitats already described, the habitats of $H$. selago in Lithuania are mainly shady, wet forests [32,33].

Populations of $H$. selago, in many cases, are composed of single or very few individuals $[2,33]$. The recorded population of $H$. selago subsp. arctica in Sulinkiai peatland, both in terms of local distribution and the number of individuals, is substantial. We have not compared differences in the frequency of the subspecies for plots having different moss cover structures (varying proportions of bare peat, covers of native Polytrichum strictum and the invasive moss Campylopus introflexus). The latter species usually forms very dense carpets that inhibit regeneration of vegetation [34]. It may also inhibit regeneration of young individuals of the subspecies, and it may be that individuals of Huperzia had established in the area before it was totally colonized by mosses. Consequently, the future of the population of $H$. selago subsp. arctica is uncertain due to possible invasive encroachment by mosses. On the other hand, open gaps in the dense cover of Campylopus introflexus, and that usually develop spontaneously due to the biology of the species [34], may be successfully exploited by regenerating individuals of Huperzia.

\section{Conclusions}

Two records from the cutover peatlands of different parts of Lithuania revealed that Huperzia selago subsp. arctica may have a more southern distribution than previously thought. However, the possibility that the subspecies may be more frequent, but under-recorded, or that similar habitats have simply been overlooked by researchers, cannot be ignored. Even so, the fact that $H$. selago subsp. arctica was recorded in only two peatlands of the 32 studied indicates that this subspecies is not widely distributed in the area, even in suitable habitats.

Such drained habitats, with disturbed natural vegetation, where peat-cutting has been abandoned and where spontaneous secondary succession has begun, are favourable for H. selago subsp. arctica and are comparable to its habitats in the northern part of the distribution area. Again, these are temporary habitats. Gradual overgrowth with shrub or tree species will eventually reduce the frequency of $H$. selago subsp. arctica, which prefers open habitats, or even cause its disappearance. Intensive anthropogenic influence may also totally destroy the habitats. Therefore, permanent management of the habitats, with only limited human impact (cutting of shrubs, destruction of dense cover of herbs or mosses, etc.), should have a positive effect on the survival of $H$. selago subsp. arctica. 


\section{Ackowledgements}

The research was funded by a grant (No. LEK 22/ 2010) from the Research Council of Lithuania.

We are grateful Dr. Henry Väre from the Finnish Museum of Natural History (Helsinki) for confirming the identity of the specimens and to Ms. Dovile Skipskyte for technical assistance.

\section{References}

1. Aiken SG, Dallwitz MJ, Consaul LL, McJannet CL, Boles RL, Argus GW, et al. Flora of the Canadian Arctic Archipelago: descriptions, illustrations, identification, and information retrieval [Internet]. 2007 [cited 2011 Oct 14]; Available from: http://nature.ca/aaflora/data/www/ ptlyhu.htm

2. Kukkonen I. Lycopodiaceae. In: Jonsell B, editor. Flora Nordica. Lycopodiaceae to Polygonaceae. Stockholm: Bergius Foundation, The Royal Swedish Academy of Sciences; 2000. p. 1-13. (vol 1).

3. Elven R. Checklist of the Panarctic flora (PAF) vascular plants [Internet]. 2007 [cited 2011 Oct 14]; Available from: http://www.binran.ru/infsys/paflist/index.htm

4. Siplivinsky VN. Zametki o baikal'skoj flore, 1. Novosti Syst Vysh Rast. 1973;10:345-361.

5. Tzvelev NN. On the northern species of the genus Huperzia (Huperziaceae). Bot Zhurn. 1999;84:81-85.

6. Sekretareva NA. Sosudistye rasteniia Rosiiskoii Arktiki i sopredel'nykh territorii. Moscow: T-vo Nauch Izd, KMK; 2004.

7. Lid J, Lid DT. Norsk flora. 6th ed. Oslo: Det Norske Samlaget; 1994.

8. Hämet-Ahti L, Suominen J, Ulvinen T, Uotila P, editors. Retkeilykasvio. Helsinki: Finnish Museum of Natural History, Botanical Museum; 1998.

9. Mossberg B, Lennart S. Den nya nordiska floran. Stockholm: Wahlström \& Widstrand; 2003.

10. Tutin TG, Burges NA, Charter AO, Edmondson JR, Heywood VH, Moore DM, et al., editors. Flora Europaea. 2nd ed. Cambridge: Cambridge University Press; 1993. (vol 1).

11. Stace CA. New Flora of the British Isles. Cambridge: Cambridge University Press; 1992.

12. Flora Europaea [Internet]. 2011 [cited 2011 Oct 14]; Available from: http://rbg-web2.rbge.org.uk/FE/fe.html

13. Laasimer L, Kuusk V, Tabaka L, Lekavičius A, editors. Flora of the Baltic countries. Compendium of vascular plants. Tartu: Estonian Academy of Sciences; 1993. (vol 1).

14. Eglïte Z, Šulcs V. Latvijas vaskulāro augu flora: Lycopodiophyta, Equisetophyta, Polypodiophyta. Riga: University of Latvia; 2000.

15. Kukk T. Eesti taimestik. Tartu: Estonian Academy Publishers; 1999.

16. Kolesnikova MP. Huperziaceae. In: Parfionov VI, editor. Flora Belarusii. Sosudistye rastenija. Minsk: Izdatelskij dom Belarusskaja nauka; 2009. p. 36.

17. Mirek Z, Piękoś-Mirkowa H, Zając A, Zając M. Flowering plants and pteridophytes of Poland - a checklist. Kraków:
W. Szafer Institute of Botany, Polish Academy of Sciences; 2002. (Biodiversity of Poland; vol 1).

18. Naujalis J. Sporiniai induočiai kaip augalų bendrijų komponentai. Vilnius: Baltic ECO; 1995.

19. Gola EM. Reproductive strategies of Huperzia. In: Szczęśniak E, Gola EM, editors. Club mosses, horsetails and ferns in Poland: resources and protection. Wrocław: Polish Botanical Society, Institute of Plant Biology, University of Wrocław; 2008. p. 5-14.

20. Kaušyla K. Klimatas ir jo ištekliai. In: Drobnys A, editor. Lietuvos TSR atlasas. Moscow: Vyriausioji geodezijos ir kartografijos valdyba prie TSRS Ministru Tarybos; 1980. p. 58-74.

21. Bukantis A. Klimatas. In: Liekis A, editor. Lietuvos dirvožemiai. Vilnius: Science of Lithuania; 2001. p. 120-131.

22. Raudonikis L. Important bird areas of the European Union importance in Lithuania. Vilnius: Lithuanian Ornithological Society, Institute of Ecology of Vilnius University; 2004.

23. Gudžinskas Z. Lietuvos induočiai augalai. Vilnius: Botanikos instituto leidykla; 1999.

24. Hill MO, Bell N, Bruggeman-Nannenga MA, Brugués M, Cano MJ, Enroth J, et al. An annotated checklist of the mosses of Europe and Macaronesia. J Bryol. 2006;28(3):198267. http://dx.doi.org/10.1179/174328206X119998

25. FloraWeb - Daten und Informationen zu Wildpflanzen und zur Vegetation Deutschlands [Internet]. 2011 [cited 2011 Oct 14]; Available from: http://www.floraweb.de

26. Dierßen K. Distribution, ecological amplitude and phytosociological characterization of European bryophytes. Berlin: Gebrüder Borntraeger; 2001.

27. Jäger EJ, Welk E. Pflanzengeographische Gliederung Europas. In: Bohn U, Neuhäussl R, Gollub G, Hettwer C, Neuhäusslová Z, Schlüter H, et al., editors. Karte der natürlichen Vegetationen Europas. Bonn: Federal Agency for Nature Concervation; 2004. p. 79-86.

28. Basalykas A, editor. Lietuvos TSR fizinè geografija. Vilnius: Mintis; 1958. (vol 1).

29. Tuittila ES, Vasander H, Laine J. Impact of rewetting on the vegetation of a cut-away peatland. Appl Veg Sci. 2000;3(2):205-212. http://dx.doi.org/10.2307/1478999

30. Nowak A. Anthropogenic habitats as sites of occurrence of endangered, rare and protected plants on the example of Opole Silesia, SW Poland. Thaiszia. 2005;15:155-172.

31. Krrištálová V, Chrtek J, Krahulcová A, Bräutigam S, Krahulec F. Populations of species of Pilosella in ruderal habitats in the city of Prague: frequency, chromosome numbers and mode of reproduction. Preslia. 2010;82:437-464.

32. Minkevičius A. Lycopodiaceae. In: NatkevičaitèIvanauskienė M, editor. Lietuvos TSR flora. Vilnius: Valstybinè politinès ir mokslinès literatūros leidykla; 1959. p. 70-81. (vol 1).

33. Tupčiauskaitė J. Huperzia selago. In: Rašomavičius V, editor. Lietuvos raudonoji knyga. Vilnius: Lututé; 2007. p. 385.

34. Equihua M, Usher MB. Impact of carpets of the invasive moss Campylopus introflexus on Calluna vulgaris regeneration. J Ecol. 1993;81(2):359. http://dx.doi. org/10.2307/2261506 